\title{
DIERENVERHALEN EN DIEREN-BIJGELOOF BIJ DE INLANDERS VAN DEN INDISCHEN ARCHIPEL,
}

Door Dr. J. P. KLEIWEG DE ZWAAN.

Wie zich een denkbeeld wil vormen van het gedachten- en gemoedsleven der op nog betrekkelijk lagen trap van ontwikkeling staande volken, dient rekening te houden met de verhalen en vertellingen bij die volken in omloop.

Die verhalen toch zijn voor zulke volken van groote beteekenis, en wel omdat het daarin medegedeelde in den regel voor werkelijk gebeurd, voor waar of mogelijk wordt gehouden; als zoodanig kunnen die fabelen en vertellingen der inlanders ons een inzicht geven in het gedachtenleven en zieleleven, welke tot die verhalen aanleiding hebben gegeven en waaruit zij zijn ontstaan.

Onder die verhalen zijn bij de meeste primitieve volken en zoo ook bij de inlanders van onzen Archipel de dierenverhalen wel zeer belangrijk, vooreerst omdat zij het meest populair zijn en verder omdat het daarin medegedeelde, ook al geven zij weer wat in vroeger tijd is voorgevallen, door menig volk nog steeds voor mogelijk wordt gehouden, of volgens de opvatting der inlanders nog altijd voortgaat te gebeuren, daar toch de dierenwereld steeds dezelfde en van denzelfden aard is gebleven. De sagen en legenden onzer inlanders, die wij als dierfabeltjes opvatten, geven voor den inlander werkelijke gebeurtenissen weer.

Die dierengeschiedenissen zijn bij onze inlanders direct op het volksgeloof gegrond, zij zijn eene uiting eenerzijds van eene nauwkeurige waarneming van de bijzondere hoedanigheden en eigenschappen der verschillende dieren, aan den anderen kant in hoofdzaak van het bij de inlanders bestaand en het volksgeloof beheerschend animisme.

De in de vrije natuur levende inlander stelt groote belangstelling in de dierenwereld, hij slaat de dieren gade, hij neemt hunne eigenaardige gewoonten waar, hij bestudeert hunne licha- 
melijke eigenschappen, waardoor zij zich van andere dieren onderscheiden.

Ten deele zijn dan ook die dierenverhalen waarschijnlijk ontstaan uit de neiging van den inlander om eene verklaring te geven van de bijzonderheden, welke hem bij die dieren opvallen. In hunne verhalen trachten de inlanders dan weer te geven en te verklaren, hoe de bijzondere, de specifieke eigenschappen der verschillende dieren zijn ontstaan. Van dergelijke verhalen wil ik hier enkele voorbeelden geven.

In de eerste plaats dan zijn er bij onze inlanders vertellingen in omloop, die omtrent het ontstaan der karakteristieke somatische eigenschappen van bepaalde dieren eene uitlegging geven. Zoo kennen bijv. de Maleiers van Malakka een verhaal, dat aangeeft, hoe het komt, dat de beer en de aap (siamang) witte vlekken op hun lichaam bezitten; in het kort weergegeven luidt het als volgt: Prinses Telan werd tijdens de afwezigheid van haar verloofde, Si Malim Bongsu, lastig gevallen door diens ouderen broeder. Ten einde aan zijn aanrandingen te ontkomen, veranderde het meisje zich in haar wanhoop in een aap, terwijl hare dienares de gedaante van een beer aannam. Op zekeren dag waren zij bezig te baden, toen zij door iemand verrast werden; zij hadden geen tijd om de zeep van haar lichaam te verwijderen en sedert dien tijd ziet men bij aap en beer witte vlekken op de huid. ${ }^{1}$

In een Toradja'sch verhaal vinden wij medegedeeld, waaraan het zwarte lichaam der apen moet worden toegeschreven: Terwijl een inlandsch ouderpaar uitgegaan was om te oogsten en hun kind had achtergelaten, kwam een aap hunne woning binnen en stal al het eten van het kind. Het geschiedde aldus verscheidene achtereenvolgende dagen, met het gevolg, dat het kind begon te vermageren, daar het onvoldoende voedsel kreeg. Op zekeren dag hadden de ouders, toen zij uitgingen, eene hoeveelheid kleefrijst achtergelaten. De aap kwam weer en begon van de rijst te eten. Terwijl hij ervan gebruikte, bleef er rijst tusschen zijn tanden kleven; hij wreef met zijn handen in het gelaat en daardoor kreeg hij kleefrijst in zijn oogen. Ten slotte zaten zijne oogen zoo vol rijst, dat hij niet meer kon zien en niet bemerkte, dat het reeds duister werd. Toen de ouders van

I Walter W. Skeat: Malay Magic, 1900. 
het kind terugkwamen en den aap bemerkten, sloegen zij het dier dood. De vader gelastte toen zijn zoontje, de ingewanden uit het dier te verwijderen. Weldra kwamen vele apen kijken, wat het kind uitvoerde. Op het zien van al die apen, moest de knaap lachen en toen de apen zijn zwarte gevijlde tanden zagen, wilden zij ook hunne tanden laten vijlen. De jongen beloofde, dat zijn vader hunne tanden zou vijlen. Deze bond toen de pooten der apen vast, voorgevende dat zulks noodig was bij het vijlen der tanden. Vervolgens bracht hij al de apen naar de rijstschuur en stak de schuur in brand. Vele apen stierven, andere, hoewel deerlijk verbrand, bleven in leven. Dat zou de reden zijn, waarom de apen tot op den huidigen dag een zwart lichaam hebben. ${ }^{1}$

Bij verscheidene stammen in onzen Oost gaat het verhaal, dat een knaap door zijn moeder gelast werd mais te halen om die te roosteren in een pan. De jongen weigerde echter te doen, wat zijn moeder hem beval, waardoor deze zoo boos werd, dat zij hem op de heete pan zette, tengevolge waarvan hij zijn partes posteriores verbrandde. Toen liep de knaap hard weg naar het bosch en werd de eerste aap. ${ }^{2}$ In een Makassaarsch dierenverhaal wordt verteld van een meisje, dat in weerwil van de bevelen harer moeder niet wilde werken. Om haar te straffen zette de moeder een braadpan op het vuur en liet het kind daarop plaats nemen. Het meisje brandde zich deerlijk, sprong van de braadpan af en ontvluchtte in het bosch, waar zij in een aap veranderde. ${ }^{3}$ Ik vermoed, dat deze zoo gelijksoortige verhalen in den Indischen Archipel moeten verklaren, waaraan sommige apen hunne onbehaarde partes posteriores danken.

$\mathrm{Er}$ bestaat ook een Atjeh'sch verhaal, waarin wordt medegedeeld, hoe het komt dat sommige apen schijnbaar geen testikels bezitten: Een schildpad had zich onder het rijstblok verborgen, waarop een aap zich had nedergezet. De aap zocht overal naar de schildpad en riep dit dier, hetwelk hem van onder het rijstblok antwoord gaf. De aap, meenende dat zijn testikels hem antwoord gaven, werd zoo kwaad, dat hij met een rijststamper

1 N. Adriani: Toradjasche Vertellingen. Tijdschr. voor Ind. Taal-, Lnnden Volkenkunde, deel 45, 1902.

2 Albert C. Kruyt: Het Animisme in den Indischen Archipel, 1906.

s B. F. Matthes: Makassaarsche en Boegineesche legenden. Bijdr. tot de Taal-, Land- en Volkenk. van Ned. Indië, 4, X. 1885. 
daarop sloeg. Zijn ruwheid werd de oorzaak, dat zijn nageslacht schijnbaar geen testikels bezit. ${ }^{1}$

Waaraan het toe te schrijven is, dat de kraai zwart van kleur is, vindt men in een Nufoorschen fabel medegedeeld: In vroeger tijd was de kakatoe zwart en de kraai wit. Op zekeren dag waren deze beide dieren bezig sagoboomen te vellen. De kraai sprak: "Indien wij een gat in den boom maken, zal de sago van zelf er uit vloeien». De kakatoe wilde echter blijven hakken. Daarover ontstond een twist, de kraai greep de kakatoe en stopte haar in de sago, waardoor zij wit werd. Daarop pakte de kakatoe de kraai beet en duwde het dier in den modder, zoodat het zwart werd. Sinds dien is de kraai zwart en de kakatoe wit gebleven. ${ }^{2}$

Een gelijksoortig verhaal bestaat bij de Maleiers van Malakka: In vroeger tijd waren de argusfazant en de kraai de beste vrienden, totdat op zekeren dag de argusfazant, die er toen nog leelijk uitzag, de kraai verzocht zijn veeren te beschilderen. De kraai wilde het wel doen, echter op voorwaarde, dat dan de argusfazant zijn veeren zou kleuren. Toen de kraai de veeren van den fazant had beschilderd en de beurt aan den fazant was gekomen om de vleugels van de kraai te kleuren, wilde de fazant dit niet doen. Daarover ontstond een twist, de argusfazant greep de pot met zwarte verf en wierp dien op de kraai. Sedert dien tijd is de kraai zwart gebleven. ${ }^{3}$

Ook in eene Soendasche vertelling wordt verhaald, waardoor de kraai zijn zwarte kleur heeft gekregen en tevens waaraan de wespen en muggen hunne giftigheid danken: In den ouden tijd was de santja de giftigste van alle slangen. De andere slangen wilden dat echter niet gelooven en toen zou de santja het bewijzen door een bruidspaar, dat in optocht rondgereden werd, te bespuwen. Dit plan werd echter vernomen door de kraai, welk dier in dien tijd nog wit was. Deze bleef boven het bruidspaar vliegen en zag, dat de santja de beide jonge lieden bespuwde, waardoor deze terstond stierven. Bij de begrafenis bleef de kraai steeds boven de begraafplaats vliegen en werd met aarde bestoven, totdat zij zwart zag. Toen begaf zich de kraai naar de santja

1 C. Snouck Hurgronje: De Atjehers, 1894.

${ }^{2}$ F. J. F. van Hasselt: Nufoorsche Fabelen en Vertellingen. Bijdr. tot de Tanl-, Land- en Volkenkunde van Ned. Indië, $7^{\bullet}$ volgr., 7e deel, 1908.

3 Walter W. Skeat: Malay Magic, 1900. 
en zei: "Uw gif is niet werkdadig, ik ben wel zwart geworden, maar dat komt, omdat ik mezelf besmeerd heb met zwartsel.» De santja geloofde zulks en in de meening, dat haar gif inderdaad niet meer werkdadig was, wierp zij het weg. Dit gif werd opgeraapt door de wespen en muggen, welke aldus hunne giftige eigenschappen hebben gekregen. ${ }^{1}$

In eene Nufoorsche vertelling vindt men ook opgegeven, hoe het komt, dat de hond vele borsten heeft en de vrouw slechts twee. Vroeger zou dat juist omgekeerd geweest zijn; toen had de vrouw vele borsten en de hond bezat er maar twee; in dien tijd kreeg de vrouw vier kinderen en de hond telkens maar één. De vrouw beklaagde zich echter eens tegenover de hond, dat zij bij het overeind loopen zooveel last ondervond van hare borsten en stelde de hond voor om te dien opzichte om te ruilen. Dit vond de hond goed en nadien kreeg de vrouw haar kinderen een voor een, terwijl de hond er vele tegelijk ter wereld brengt.

Een Rottineesch verhaal, waarin medegedeeld wordt, hoe het te verklaren is, dat bij het rund het vel steeds zeer ruim om het lichaam zit, luidt als volgt: Een rund, dat bevriend was met een buffel, ging op zekeren dag met dat dier op een grasveld grazen. Dien dag was het zeer warm, de beide dieren konden het van de hitte niet uithouden en ontdeden zich daarom van hun huid, om in de rivier te gaan baden. Plotseling begon het te regenen en kwamen het rund en de buffel, bevreesd dat hunne huiden nat zouden worden, uit het water om ze weder aan te trekken. In zijn haast deed toen echter het rund het buffelvel om en de buffel de huid van het rund. Voor het rund was de buffelhuid veel te ruim, terwijl den buffel het vel van het rund zeer gespannen om het lijf zat. Tengevolge daarvan is het, dat tot heden toe, al is een rund nog zoo vet, zijn vel ruim om het lichaam, terwijl bij den buffel, al is hij mager, het vel gespannen om zijn lichaam zit. ${ }^{2}$

Waaraan het moet worden toegeschreven, dat zich in den schedel van den kaaiman zoo veel putjes bevinden, verklaart

1 R. A. Kern: Eenige Soendasche Fabels en Vertelsels. Bijdr. tot de Taal-, Land- en Volkenk. van Ned. Indië, 7e volgr.. 6e deel 1908.

2 J. C. G. Jonker: Bijdrage tot de kennis der Rottineesche tongvallen. Bijdr. tot de Taal-, Land- en Volkenk. van Ned. Indië, deel 68, 1913. Dl. 71 . 
ons eene Galelareesche vertelling: $\mathrm{Er}$ was eens een visch, bruinvisch genaamd, die onder het duiken placht te zingen "den kaaiman zelfs smoor ik in een bamboe, den haai zelfs smoor ik in een bamboe». Toen de kaaiman en de haai dat liedje vernamen, werden zij bevreesd. De haai vluchtte op een koraalgewas, vol spleten en reten, en drong er in door, tengevolge waarvan de schedel van dit dier een platten vorm kreeg. De kaaiman ontvluchtte in een boschaadje en verborg zich in een baroe-boom (hibiscus tiliaceus), waar de witte mieren een nest in zijn schedel maakten en putjes daarin groeven. ${ }^{1}$

Uit een andere Galelareesche fabel vernemen wij, hoe de zeeslak haar puntig hoornschelpje heeft gekregen: Op zekeren dag stelde de ijsvogel de zeeslak voor om eens om 't hardst te loopen. De slimme zeeslak waarschuwde toen haar makkers en verzocht hen, telkens als zij den ijsvogel zagen aankomen, te roepen: "vriend, hier ben ik!, De ijsvogel vloog zoo hard hij kon, maar telkens als hij zich nederzette, riep een zeeslak "vriend, hier ben ik!», zoodat de vogel voortdurend in den waan was, dat de zeeslak, met welke hij de weddingschap had aangegaan, hem vóór was geweest. Eindelijk viel de vogel van uitputting neder; toen moesten de slakken zoo lachen, dat zij hun achterste op den grond stootten, waardoor dat deel zeer puntig werd, ja van sommige de punt zelfs afbrak. Sedert dienhebben de zeeslakken zoo'n puntig hoornschelpje en ontbreekt bij sommige de punt.

Omtrent het geknikte lichaam van de wespen bezitten de Toradja's het volgend verhaal: In vroeger tijd was de wesp een man, de garnaal en de slak waren zijn vrouwen. Op zekeren dag zei de wesp tot zijn beide vrouwen, dat hij den volgenden morgen vroeg boomen zou gaan vellen, en dat zij zijn eten in 't bosch moesten brengen. Toen de garnaal en de slak het eten naar hun man brachten, stierven zij onderweg. De wesp, die honger had gekregen, ging eens kijken, waar zijne vrouwen bleven en vond hen dood op den weg liggen.

$\mathrm{Hij}$ haalde toen een stuk hout en bond aan elk uiteinde een zijner vrouwen, ten einde ze op zijn schouder naar huis te vervoeren. De last was hem echter te zwaar, en dientengevolge

1 M. J. van Baarda: Fabelen, Verhalen en Overleveringen der Galelareezen. Bijdr. tot de Taal-, Land- en Volkenk. van Ned. Indië, $6^{\circ}$ volgr., eerste deel, 1895. 
brak zijn rug door. Zoo komt 't, dat men ook nu nog de wespen steeds met een geknikt lichaam ziet. '

In eene andere Toradja'sche vertelling vindt men medegedeeld, waardoor de jaarvogel zijn witten ring om den hals heeft gekregen: Vroeger had de groene duif een witte halsketen om. De jaarvogel, die op een feest wilde gaan, vroeg aan de duif haar ketting te leen. De duif voldeed aan het verzoek, maar kreeg nimmer haar keten terug. Daardoor komt het, dat tot op dezen dag de jaarvogel een witte kraag bezit en dat de duif niet ophoudt te weenen tot op den huidigen dag.

Waardoor het te verklaren is, dat de ongo (Leptocorisa acuta) geel van kleur is en de dongge dai (een lange, groene sprinkhaan, met hamervormigen kop) een paar uitwassen aan den kop bezit, wordt door de Toradja's in Celebes als volgt verhaald: De ongo had de dongge dai tot vrouw, doch op een goeden dag kregen die twee genoeg van elkaar; de ongo verweet zijn vrouw, dat zij zulk een langgerekt lichaam had en de dongge dai klaagde er over, dat haar man zoo stonk. Zij scheidden dus en ieder ging zijns weegs; de dongge dai maakte zich een kapsel aan beide zijden van het hoofd en de ongo behandelde zijn lichaam met kurkuma. $\mathrm{Na}$ eenigen tijd zagen zij elkander terug en waren zoo vol bewondering, dat zij op nieuw besloten te huwen. ${ }^{2}$

Door Hose wordt eene Dajaksche vertelling medegedeeld, welke aangeeft, waaraan het toe te schrijven is, dat de beliravisch zooveel graten bezit: De visschen klaagden erover, dat zoovele van hen door de menschen werden gevangen, die, om de visschen te verdooven, toeba-gif in het water wierpen. $\mathrm{Zij}$ besloten toen een dayong (zielevanger) te kiezen, die regen kon maken en daardoor verhinderen kon, dat het water vergiftigd werd.

Echter geen enkele visch wilde dayong zijn, totdat ten slotte de belira-visch zich daartoe aanbood, op voorwaarde evenwel, dat alle andere visschen hem een hunner graten zouden afstaan Dit voorstel werd aangenomen en aldus verkreeg de belira zooveel graten. ${ }^{3}$

1 N. Adriani: Toradja'sche Vertellingen. Tijdschr. Ind. Taal-, Land- en Volkenk., deel 45, 1902.

2 M. Adriani en Alb. C. Kruyt: De Bare'e-sprekende Toradja's van MiddenCelebes, deel III, 1914.

3 Charles Hose and W. Me Dougall: The Pagan Tribes of Borneo, 1912. 
De Maleiers van Malakka bezitten een verhaal, waarin eene uitlegging wordt gegeven van het feit, dat de těkukur-duif een ring van witte spikkels om den hals heeft: Een meisje leefde met hare ouders midden in het bosch. Haar vader was bezig op eenigen afstand van hunne woning een stuk grond te ontginnen, om daarop rijst te kunnen planten.

Voortdurend smeekte zijn dochtertje met hem mede te mogen gaan naar het veld, maar dat werd haar steeds verboden. Ten einde raad veranderde zij zich, na al haar sieraden te hebben afgelegd, in een tekukur. Alleen haar halsketting had zij omgehouden en deze veranderde in de ring van witte spikkels. ${ }^{1}$

Een aap had op listige wijze een ouden man zijn gong ontvreemd. Het schreien van den bestolene werd gehoord door een krab, die tegen belooning van een buffel beloofde de gong te zullen terugbrengen. De krab klom in een boom en greep met zijn scharen de hand van de aap, die van schrik de gong liet vallen. Toen de oude man de beloofde buffel aan de krab gaf, leidde deze het dier naar een gat. De buffel trapte op de krab, vandaar dat dit dier plat van gedaante is. De krab echter kneep de hoeven van den buffel, die dientengevolge tot op den huidigen dag gespleten zijn. Van pijn rende de buffel weg, maar trapte bij ongeluk op de staart van den kwartel. Vandaar komt het dat de kwartels geen staart meer hebben. De kwartel vloog toen tegen de horens van het paard, dat sinds dien tijd zijn horens moet missen. ${ }^{2}$

Volgens een Javaansch verhaaltje werd eens de slang door een dandang-vogel bedrogen. Daarover vertoornd vervolgde de slang de dandang voortdurend, welk dier dientengevolge geen rust had en geen tijd kon vinden om eten voor zich te zoeken. Eindelijk begon het de dandang te vervelen; hij verzon een list. Hij vloog naar de desa, waar iemand bezig was indigo te bereiden. Fluks wentelde hij zich om en om in de tjêding (steenen bak) met indigo, waardoor zijn witte vederdos donker van kleur werd. Daardoor wist hij de slang te misleiden en aan diens vervolgingen te ontkomen. Tevens veranderde bij die gelegenheid de dandang van naam en heette sedert dien gagaq, zwarte kraai. ${ }^{3}$

1 Walter W. Skeat: Malay Magic, 1900.

2 M. Joustra: Iets over Bataksche Literatuur. Meded. vanwege het Ned. Zendel. Gen. 1903.

s S. Luinenberg: Javaansche Verhalen. Meded. v.w. het Ned. Zend. Gen., 1905. 
In eene Dajaksche legende verzoekt de roewei (argusfazant) de boeboet met vruchtensap een paar mooie figuren op zijn staart te willen teekenen. De boeboet voldoet aan het verzoek en toen hij klaar was, draaide hij zich om ten einde zich ook te laten beschilderen. Maar de ondankbare roewei spuwde hem een mondvol sirihsap over het lichaam en vloog weg. Op deze wijze kreeg de boeboet zijn rosse kleur. Nu vervloekte de boeboet den roewei, zeggende: "gij zult altijd in het oerbosch moeten blijven; als je in de bawas (het lage hout) komt, moet je sterven». De roewei, dit hoorende, sprak echter: "en jij zult altijd in de bawas blijven en moogt nimmer het oerwoud in. En zoo is het altijd gebleven.

Er bestaat ook een Dajaksch verhaal, volgens hetwelk de kraai de vederen van den fazant versierde, waarna deze over den gagaq de pot met kleurstof, die gebruikt was, leeggooide, waardoor het dier een zwarte kleur heeft gekregen. ${ }^{i}$

Door Westenenk wordt nog een ander verhaal medegedeeld, het verhaal van Boedjang, die in een kampong kwam, waar hij menschen ontmoette, die hij ontmaskerde als te zijn krokodillen. Een panische schrik beving de ontmaskerde boeajamenschen, zij gingen op de vlucht en het water in. Boedjang ging weg, maar de boeaja's lieten hem niet met rust en bestookten hem voortdurend, maar telkens als een krokodil zijn kop uit het water stak, strooide hij het dier sěkam (zemelen) in de oogen. Daardoor hebben de krokodillen tot op den huidigen dag gezwollen oogen. -

Eene andere categorie van dieren-verhalen geeft eene verklaring van de eigenaardige gewoonten van sommige dieren.

$\mathrm{Er}$ is een Maleisch verhaal, waarin wordt medegedeeld, waarom de kat haar faeces met aarde pleegt te bedekken: De kat had den tijger en den beer in de leer genomen; al wat zij zelf kende en wist, onderwees zij aan deze beide dieren : sluipen, springen, gluren, wat niet al. In één punt maakte zij echter een onderscheid tusschen haar beide leerlingen, den beer gaf zij namelijk ook les in het boomklimmen, welke kunst zij den tijger onthield. Deze vroeg de kat, waarom hij niet mocht leeren klimmen, waarop de tijger ten antwoord kreeg, dat hij

-1 L. C. Westenenk: Bijdragen tot de kennis der folklore van West-Borneo. Tijdschr. Ind. Taal-, Land- en Volkenk., deel 43, 1901. 
dan van uit de boomen zou kunnen te weten komen, waar de menschen verblijf houden en deze zou opeten.

De tijger, dit vernemende, werd woedend en zwoer de kat eeuwige haat. "Niet alleen haar, maar zelfs haar uitwerpselen zal ik opvreten, waar ik ze maar aantref, , aldus zwoer hij. Om die reden neemt van dien dag af de kat de voorzorg haar faeces te begraven. ${ }^{1}$

Een Rottineesch verhaal leert ons, waarom de wilde duif seku-oèk roept: Ten tijde toen de hemel zich naar boven terugtrok, waren daar vele menschen, die boven moesten blijven, terwijl andere op de aarde achterbleven. Juist op dat oogenblik was een knaap, die in den hemel woonde, op de aarde gekomen; hij was geheel verdiept in het spel met zijne makkers en merkte niet, dat de hemel naar boven werd getrokken. Toen hij opkeek, dacht hij aan zijn moeder, Bei-Sekuk geheeten en wilde hij naar den hemel terug. Echter hij wist niet, hoe hij er moest komen en begon te huilen, tot zijn moeder roepende "Sekuoèk, Sekuoèk, waar zijt gij ? Waarom hebt gij mij alleen gelaten, ik heb grooten honger, stuur mij wat voedsel om te eten!» Bei-Sekuk sprak daarop tot haar kind: "Hoe zal ik $U$ iets te eten kunnen zenden, daar de houtworm de trap met kronkels heeft ingevreten, zoodat wie boven is, niet naar beneden komen kan en wie beneden is, niet meer naar boven. Verlang nu niet meer naar gekookt eten, maar zoek gierst en rijstkorrels om te eten., En de knaap kreeg vleugels, waarmede hij overal heenvloog. Tot op den huidigen dag, als de wilde duif in den regentijd geen rijst- of gierstkorrels vindt, roept hij : suku-oèk. ${ }^{2}$

Hoe het komt, dat de kasuaris niet kan vliegen, vernemen wij uit een Nufoorsche fabel: In vroeger tijd was de kasuaris een echte vogel, hij vloog gelijk de andere vogels. Op zekeren dag zochten de kasuaris en de jaarvogel boomvruchten, maar telkens als de kasuaris op een tak ging staan, vielen de vruchten terstond naar beneden. De jaarvogel stelde toen den kasuaris voor, om onder de boomen naar vruchten te zoeken. Aldus deden zij en toen sprak de jaarvogel tot den kasuaris:

1 G. A. N. Scheltema: Zeven dierenverhalen. Bijdr. tot de Taal-, Landen Volkenk. van Ned. Indië, VII, 1900.

2 J. C. G. Jonker: Rottineesche Verhalen. Bijdr. tot de Taal-, Land- en Volkenk. van Ned. Indië, $7^{\circ}$ volgr, $4^{\mathrm{e}}$ deel, 1905. 
"Laten we onze veeren uittrekken, ik zal de uwe eerst uittrekken, trek gij dan daarna de mijne uit!» De kasuaris vond dat goed, maar toen de jaarvogel zijn veeren had uitgetrokken, vloog hij hard weg. Sedert dien kan de kasuaris niet, meer vliegen. ${ }^{1}$

Een Rottineesch verhaaltje verklaart ons, waaraan het toegeschreven moet worden, dat de koak (een vogel) zingt: de koak en de tainaük (een klein vogeltje) waren met elkaar bevriend. Eens daagden zij elkaar uit om op elkanders pooten te trappen, of de een misschien de pooten van den ander zou kunnen breken. Het gelukte de tainaük op listige wijze met een steentje de pooten van de koak stuk te slaan. De koak ontvluchtte toen naar den heuvel om daar een heelmeester te zoeken. Eindelijk kwam het dier in het huis van Boela-kai (de maan) en in dat van Lèdo-hòro (de zon) en smeekte deze om hulp. Zoowel de zon als de maan hadden medelijden met de koak en behandelden de gebroken pooten, zoodat deze weer genazen. Daarna keerde de vogel weer naar de aarde terug. Uit dankbaarheid voor de hulp van de zon en de maan genoten, pleegt de koak nu 's morgens en 's avonds te zingen. ${ }^{2}$

Wegens het volgende voorval vliegt de uil slechts in de nacht: de vogels hadden onder elkaar eene weddingschap aangegaan, wie van hen tot in den hemel zou kunnen vliegen. Het slimme kolibrietje nam een stukje hout mede en ging zitten op den rug van den jaarvogel, zonder dat dit dier het bemerkte. Toen de jaarvogel niet meer hooger vliegen kon, verliet het kolibrietje zijn schuilplaats en vloog nog een eind hooger, veel hooger dan alle andere vogels. Echter slaagde het diertje evenmin er in den hemel te bereiken.

Toen het kolibrietje op de aarde was teruggekeerd, beweerde het in den hemel te zijn geweest en toonde als bewijsstuk het houtje, dat hij uit den hemel zou hebben medegebracht. De andere vogels werden toen jaloersch en joegen de kolibrie na, die zich verschool in een muizenhol. Aan den uil werd opgedragen vóór het muizenhol de wacht te houden, opdat de kolibrie

I F. J. F. van Hasselt: Nufoorsche Fabelen en Vertellingen. Bijdr. tot de Taal-, Land- en Volkenk. vau Ned. Indië, 7e volgr., 7e deel, 1908.

2 J. W. Toepoe, geciteerd door J. C. G. Jonker: Bijdrage tot de kennis der Rottineesche Tongvallen. Bijdr. tot de Taal-, Land- en Volkenk. van Ned. Indië, deel 68, 1913. 
niet zou kunnen ontsnappen. Echter de uil viel in slaap en de kolibrie wist te ontkomen. Toen werden de vogels boos op den uil en achtervolgden dit dier. De uil verborg zich tusschen de lianen en durft sedert dien alleen 's nachts zijn schuilplaats te verlaten, uit vrees voor zijn vervolgers.

Eens spraken de witte kakatoea, de kraai, de boschkip en de parkiet af om te gaan sagokloppen. Onder het werk kregen zij echter ruzie met elkaar. De kraai pakte de kakatoea, die toen nog zwart was, beet en stopte het dier in het schuim van 't water, waarin de sago uitgeperst was. Dientengevolge werd de kakatoea wit. Daarop wreef de kakatoe den kraai door het slijk, waardoor deze zwart werd. De kraai en de kakatoe grepen toen den steel van den sagoklopper en sloegen daarmede den parkiet achter het oor. Dit is de oorzaak, waarom de parkiet onder het vliegen steeds den kop scheef houdt. ${ }^{1}$

Volgens eene Alfoersche vertelling ontmoetten de langkou en de moupou (twee vogels) elkander in het bosch. $\mathrm{Zij}$ zagen een dikken breeden wortel, waarin eene kleine holte was. De moupou bemerkte, dat hij zijn poot in dit gat kon steken en bedekte het met wat mos. Daarna stelde hij den langkou voor: "zoo gij wilt, laten wij dan een weddingschap aangaan door tegen dezen dikken wortel te schoppen; wie er een gat in kan maken, is de sterkste». De langkou begon, maar het gelukte dit dier niet een gat in den wortel te krijgen. Daarna was de beurt aan den moupou, die juist op de plaats trapte, waar zich het gat bevond, dat hij met mos had bedekt. Hij zei toen tot den langkou: "zie, ik ben waarlijk sterker dan gij». De langkou werd erg boos en beschaamd en trapte uit nijd op een der pooten van de moupou, zoodat deze brak. Sedert dien tijd hinken alle moupou's. ${ }^{2}$

Hoe het verklaard moet worden, dat bij nieuwe maan de dadūa, guru- en kapunani-vischjes in de monding der Tiāborivier komen, vinden wij in een Galelareeschen fabel weergegeven:

Vrouw Kasòmòno vrijde met een slang. Dit werd door haar

1 H. van Dyken en M. J. van Baarda: Fabelen, Verhalen en Overleveringen der Galelareezen.

Bijdr. tot de Taal-, Land- en Volkenk. van N. Indië, $6^{\bullet}$ volgreeks, eerste deel, 1895.

2 N. Ph. Wilken: Alfoersohe Vertelsels en Raadsels. Meded. vanwege het Ned. Zendel. Gen. 1886. 
broeders bemerkt, die besloten het dier te dooden. In haar wanhoop over den dood van de slang, vatte Kasòmòno het plan op zich te verdrinken. Tot haar kinderen, die haar in het water wilden volgen, riep zij: "kindertjes! blijft daar, tot de opkomst van de nieuwe maan; wacht op mijn luizen, mijn neten en mijn kleerluizen!» Toen dook zij onder en was niet meer. Daarom, zoo zegt men, verschijnen op bepaalde tijden des jaars, bij nieuwe maan, zekere kleine vischjes in de monding der Tiāborivier, en wel de dadūa, guru- en kapunani-vischjes, zijnde de luizen, neten en kleerluizen van Kasòmòno. (M. J. van Baarda).

Volgens de Maleiers van Selangor zouden de olifanten nimmer den djawi-djawiboom naderen, omdat eens die boom gelikt is door een armadillo. Een olifant, die de onaangename lucht aan den boom bemerkte, deed een eed nimmer zulk een boom te zullen naderen. Sedert dat oogenblik is de djawi-djawiboom de eenige in het woud, die steeds door de olifanten wordt gemeden. ${ }^{1}$

Het eigenaardig geschreeuw van den barau-barau-vogel wordt door deze inlanders op de volgende wijze verklaard: deze vogel was in vroeger tijd een bidan (vroedvrouw). De kraamvrouwen, die de hulp dezer vroedvrouw hadden ingeroepen tijdens hare bevalling, weigerden echter de diensten der bidan te beloonen. Toen het geduld der vroedvrouw uitgeput raakte, begon zij vreeselijk uit te varen; op dat oogenblik veranderde $z i j$ in een barau-barau, wiens geschreeuw nog steeds gelijkt op dat eener kijvende oude vrouw.

De enggang-vogel schreeuwt voortdurend rang-rang om den volgenden reden: op zekeren dag braken twee inlanders bij een ouden man in om hem te berooven en sloegen hem dood. $\mathrm{Zij}$ pakten het lijk in een mat, terwijl zij de buit in een anderen mat verborgen. Toen zij onraad bespeurden, liepen zij hard weg, maar namen in hun haast het pak mede, waarin het lijk was verborgen. Tegen den avond, toen het reeds donker was, bemerkte een der beide mannen de vergissing. Hij riep, wijzende op het pak, zijn medgezel toe korang»! (de man!). Deze keek om en zag den voet van zijn slachtoffer van onder de mat te voorschijn komen, waardoor hij zoo schrikte, dat hij in een enggang veranderde en sinds dien steeds maar roept: rang, rang.

1 Walter W. Skeat: Malay Magic, 1900. 
Volgens een Dajaksch verhaal zou de kritjauwei-vogel zoo nijdig en heftig schreeuwen, alsof hij voortdurend scheldt, omdat de schildpad, aan welke hij in overoude tijden de schaal heeft geleverd, nog maar steeds het geld daarvoor niet heeft betaald. ${ }^{1}$

Er bestaan bij onze inlanders ook verhalen, welke verklaren de ingeboren haat, die bepaalde dieren tegen elkaar koesteren. De verhalen omtrent den haat tusschen honden en katten, katten en tijgers, tusschen katten en muizen of ratten, heb ik reeds in andere bijdragen medegedeeld. Hier wil ik nog slechts mededeelen een Toradja'sch verhaaltje, dat verklaart de vijandschap tusschen de paling en de oeverzwaluw (djindji-kee): de oeverzwaluws hebben de gewoonte ook 's nachts te piepen en dit brengt de palingen in de war, die meenen, dat de ochtend dan reeds is aangebroken, en dan ophouden met voedsel te zoeken. Daarom aast de paling steeds op de jongen van de djindji en trekt ze bij de pooten in het water, terwijl de oeverzwaluw zijn nest bevestigt aan de takken der boomen en den stam der boomen glad makkt om den paling het opklimmen te beletten. ${ }^{2}-$

Eene derde reeks verhalen onzer inlanders geeft weer, hoe sommige dieren aan hunne namen zijn gekomen.

In een Lòda'sch verhaal vindt men vermeld, waarom de steltlooper taòko heet: $\mathrm{Er}$ was eens een getrouwd paar aan de kust, bij hetwelk de moeder der vrouw inwoonde. Bij zekere gelegenheid verweet de oude vrouw haar dochter, dat $\mathrm{zij}$ onfatsoenlijk was geweest, waardoor deze zoo beschaamd werd, dat zij zich in de zee wilde verdrinken. Hare kinderen, die hun moeder in het water zagen gaan, riepen voortdurend eina! ta òko!s, d. w. z. "moeder, ik kom in zee.» Toen de ongelukkige vrouw bij het diepe water was gekomen, verdronk zij niet, maar veranderde in een walrus. De kinderen, die in een boom bij het strand waren geklommen, riepen nog maar steeds ta òko. Plotseling veranderden zij in steltloopers, welke sedert dien nog steeds ta òko roepen en daaraan hun naam danken. ${ }^{3}$

1 L. C. Westenenk: Bijdragen tot de kennis der folklore van West-Borneo. Tijdsehr. Ind, Taal-, Land- en Volkenkunde, deel 43, 1901.

${ }^{2}$ N. Adriani en Albert C. Kruyt: De Bare'e-sprekende Toradja's van Midden-Celebes, deel III, 1914.

3 M. J. van Baarda: Lòda'sche Teksten en Verhalen. Bijdr. tot de Taal-, Land- en Volkenk. van Ned. Indië, $7^{\circ}$ volgr., 2 $2^{\mathrm{e}}$ deel 1904. 
Aan het volgende voorval ontleent de duif haar naam kalasi: Een man, Doepelopa geheeten, had twee kinderen, een jongen en een meisje. De jongen was een deugniet en voerde niets dan kattekwaad uit. Zijn vader, die ten einde raad was, besloot Kalasi, zoo was de naam van den jongen, in een vogel te veranderen, daar hij toch tot niets wilde deugen. Door zijn tooverkracht veranderde hij den knaap in een duif, die sedert dien den naam kalasi draagt. ${ }^{1}$

Volgens eene Boegineesche legende ontleenen de vliegende visschen hun naam "to-warâni, aan het feit, dat iemand zoo vermetel (warâni) was in het huwelijk te treden met zijn eigen zuster. ${ }^{2}$

De goudvisch heeft zijn naam gekregen, volgens een Soendaneesch verhaal, door de volgende gebeurtenis:

Een arme man, Miskin genaamd, had een ring gekregen, welke de eigenschap had alles in goud en edelgesteenten te veranderen. Door dezen ring was Miskin een welvarend man geworden. Echter een goudsmid wist hem den ring te ontstelen en verborg dien in een kist. Een kat en een hond, wier leven in vroeger tijd door Miskin gered was, beloofden hem den ring terug te bezorgen. De kat ving eenige muizen en liet deze een gat in de kist bijten, waardoor hij den ring uit de kist kon verwijderen. Hij gaf het waardevolle voorwerp aan den hond met de opdracht den ring aan Miskin te geven. Onderweg liet echter de hond bij ongeluk den ring in het water vallen, welke toen door een visch werd opgeslokt. De otter wist echter deze visch te vangen en bracht hem op 't drooge. Zoodoende kreeg Miskin toch zijn ring terug. De visch, die den ring had ingeslikt, draagt sedert dien tijd den naam van goudvisch. ${ }^{3}$

Waarom de Maleiers van Malakka den grijzen zeearend burang hamba siput (slaaf van den schelvisch) noemen, vinden wij door Skeat (Malay Magic) als volgt medegedeeld:

Het is de taak van dezen vogel om door zijn geschreeuw den schelvisch de verandering van eb en vloed aan te duiden, opdat het dier daarnaar zijn zwemmen kan regelen.

1 J. C. G. Jonker: Bijdrage tot de kennis der Rottineesche Tongvallen. Bijdr. tot de Taal-, Land- en Volkenk. van Ned. Indië, deel 68, 1913.

2 B. F. Matthes: Boegineesche en Makassaarsche Legenden. Bijdr. tot de Taal-, Land- en Volkenk. van N. Indië, $4^{\bullet}$ volgr., $1^{\circ}$ deel, 1885.

s R. A. Kern: Eenige Soendasche fabels en vertelsels. Bijdr. tot de Taal-, Land- en Volkenk. van Ned. Indië, 7e volgr., deel 6, 1908. 
De burong demam (koortsvogel) zou volgens de inlanders van Malakka aldus geheeten zijn, omdat het vrouwtje, als ze zware koorts heeft en door hare ziekte zelf geen voedsel kan zoeken, haar mannetje door haar koortsąchtig geschreeuw te kennen geeft en aanspoort voor haar voedsel te halen. -

Het is juist van wege de karakteristieke eigenschappen van sommige dieren, hetzij functioneele of somatische, dat onze inlanders voor bepaalde doeleinden gaarne van die dieren gebruik maken, in andere gevallen daarentegen die dieren zooveel mogelijk vermijden.

Het eerste, dat wil dus zeggen, de aanwending van bepaalde dieren of van bestanddeelen van die dieren afkomstig, heeft vooral, echter niet uitsluitend, voor therapeutische doeleinden plaats. Deze therapie kan op twee verschillende principes berusten, n.l. op de leer der transmigratie of op dien der signatuur. Volgens de transmigratieleer worden bepaalde ingrediënten toegepast met de bedoeling de werkelijke of vermeende eigenschappen dier bestanddeelen te doen overgaan op dengene, die daarvan gebruik maakt, terwijl op grond van den leer der signatuur bepaalde middelen aan den patient worden toegediend naar aanleiding van het feit, dat deze middelen een of andere eigenschap (b.v. kleur, vorm of naam) gemeen hebben met de ziekte, waaraan de patient lijdende is.

Geven wij eerst eenige voorbeelden van eene therapie, welke op transmigratie berust, voor zoover althans daarbij van dieren wordt gebruik gemaakt:

Het uitvallen der hoofdharen meenen de Javanen te kunnen bestrijden met olie, waarin een Javaansche vogelspin geweekt is. Aan het organisme dezer groote spin (Mygale Javanensis Dol.) wordt het vermogen toegeschreven de glanzend zwarte haren voort te brengen, waarmede haar lichaam begroeid is. Dit vermogen heet over te gaan in het constituens, de olie, en bij aanwending dezer als haarsmeersel in de huid van het hoofd, met het resultaat, dat ook op de hoofdhuid weder fraai-glanzende zwarte haren groeien.

Het inwendig gebruik der tjietjaks (hemidactylus frenatus Schl.) bij lepra door de Javanen berust op de regenereerende kracht, die deze dieren in hun staart bezitten.

Wanneer een tjietak zijn staart verliest, groeit deze spoedig opnieuw aan, bij lepra heeft somtijds verlies van lichaamsdeelen 
plaats en meent men, dat door aanwending van den tjietjak deze weer zullen regenereeren.

Indien bij eene vrouw de bevalling vertraging ondervindt, geven de Javanen haar arak te drinken, waarin joejoe-krabben opgestoomd zijn. Deze landkrabjes hebben de eigenaardige gewoonte haar eieren te bewaren buiten het lichaam, namelijk tusschen de draadachtige aanhangsels, die zich onder de staart bevinden. Door deze therapie meenen de inlanders te kunnen bewerken, dat ook de vrucht der barende spoedig buiten haar lichaam geraakt.

Bekend is het vermogen der stekelvarkens om bij dreigend gevaar hunne pennen te kunnen opzetten. Deze creatieve kracht zou overgaan in het lichaam van dengene, die het bloed of de maag van zulk een dier nuttigt; vandaar dat deze bestanddeelen als medicament bij impotentie worden toegediend.

Met dezelfde bedoeling beveelt men ook het gebruik van gedroogde zeeegels (Echinus-soorten) aan, daar deze eveneens bij dreigend gevaar hunne pennen oprichten. ${ }^{1}$

Wanneer een Toradja een splinter uit eenig lichaamsdeel wil verwijderen, bespuwt hij de plek, waar de splinter is ingedrongen, met het afschraapsel van een schildpadskop. De schildpad heeft het vermogen om zijn kop naar believen onder zijn schild terug te trekken en weer daaruit te voorschijn te doen komen. Men meent nu, dat eenig bestanddeel van dit dier aan den mensch toegediend, iets dat ingedrongen is, te voorschijn kan halen. ${ }^{2}$

Gelijk gezegd is het niet alleen voor therapeutische doeleinden, dat de inlanders op grond van den transmigratieleer van bepaalde dieren of van bestanddeelen, afkomstig van deze dieren, gebruik maken.

De reeds genoemde eigenschap van den schildpad zijn kop onder het schild te kunnen terugtrekken, geeft sommigen inlanders aanleiding eene nabootsing van dit dier als matakau te gebruiken. Prof. Martin ${ }^{3}$ deelt ons mede, dat de regent van Tuhaha, dien men bestolen had, tot een matakau zijn toevlucht nam om het geld weder terug te krijgen. Uit gabbagabba maakte hij twee

1 Vorderman: De transmigratie- en signaturenleer in de Javaansche geneeskunde. Feestbundel aangeboden aan Dr. P. J. Veth. 1894.

2 Albert C. Kruyt: Het animisme in den Indischen Arehipel, 1906.

$3 \mathrm{~K}$. Martin: Reisen in den Molukken. 
voorwerpen, een krokodil en een schildpad voorstellend, welke onder een afdak werden geplaatst. De bestolene sprak een tooverformule uit, waardoor de dief met ongeluk werd bedreigd, namelijk door een krokodil opgevreten te zullen worden. De schildpad beoogde, den schuldige een geslachtsziekte te veroorzaken, waarbij de penis zich terugtrekt, gelijk een schildpad in staat is zijn kop terug te trekken.

Zoo plegen b.v. de Javanen aan dansmeiden (ronggengs) een sondari-worm (Megascolex musicus Horst) in gepoften staat toe te dienen. Deze worm pleegt namelijk 's nachts in hoogen toon een schril geluid voort te brengen; men gelooft, dat door het gebruik van zoo'n worm de ronggengs, als zij zich schor hebben geschreeuwd, het vocale gedeelte van haar beroep opnieuw naar behooren kunnen uitoefenen.

Eene Javaansche vrouw, die haar man onder den duim wil houden of krijgen, ziet zich een moeka te verschaffen en snijdt dit beestje den hals af. De moeka (nycticebus tardigradus) is een halfaapje, dat overdag in rustige houding den kop tegen de borst gedrukt houdt en de armen over den kop heenslaat, als ware het een toonbeeld van deemoed en onderdanigheid. De afgesneden kop van het dier wordt gekookt; de schedelbeenderen reinigt men daarna zorgvuldig, waarna ze worden gedroogd. Dan wordt heimelijk een stukje van het schedeldak in de gendi (kruik) gedaan, waaruit de man zijn water pleegt te drinken. Bij het slachten van het dier prevelt de vrouw: "zeg eens man! denk er aan dat je alles doet, wat mij behaagt en niets verricht buiten mijn weten!» De kracht, door het prevelen van de spreuk onder het slachten van den moeka in diens kop gebracht, moet in het drinkwater overgaan en daarmede in het lichaam van haar echtgenoot, die nu alles zal opvolgen, wat den moeka is voorgezegd (Vorderman).

Op Halmahera plegen de Galelareezen met de asch van verbrande kattenhaar zich in te wrijven vóór het aangaan van een gevecht, ten einde goed te land te komen, wanneer men onverhoopt mocht komen te vallen. Daar de kat een dier is dat, wanneer het valt, bijna steeds op zijn pooten terecht komt en zich niet bezeert, is men overtuigd, dat bestanddeelen van de kat afkomstig deze eigenschap op den mensch kunnen overbrengen.

De Toradja's laten de meisjes, welke bij het mompari-langka 
de wijding tot priesteres ondergaan, aan den snavel van een haan zuigen, opdat zij evenals dit dier een fraaie stem zullen krijgen, wat hun bij het voordragen der litanieën zeer te pas komt. ${ }^{1}$

Op transmigratie berust ook het gebruik der Bataks in Sumatra om aan kinderen, zoodra zij oud genoeg zijn om vleesch te eten, als eerste vleeschspijs ambaroba (een soort merel) te eten te geven. De ambaroba heeft namelijk een heldere stem en dus zal door het gebruik van 't vleesch van dit dier het kind later ook een mooie stem krijgen. ${ }^{2}$

Wanneer een Javaan door den doekoen van een of andere ziekte is genezen, geeft hij aan dezen wel bij voorkeur een ajam boekoeng, een staartlooze kip ten geschenke, hopende daardoor te bereiken, dat zijn ziekte geen "staartje» zal hebben. ${ }^{3}$

In Zuid-Celebes plegen de inlanders wel ten einde oneenigheid tusschen gehuwde lieden te veroorzaken, onder hun hoofdkussen honden- en kattenhaar te verbergen. Men meent, dat dientengevolge de beide echtgenooten ook als hond en kat, als vijanden dus, met elkaar zullen leven. ${ }^{4}$

Bij de Karo-Bataks wordt, als de bevalling eener vrouw bijzonder moeilijk is, aan de barende stukjes van de huid eener paling toegediend. ${ }^{5} \mathrm{Ik}$ veronderstel, dat daarvan de bedoeling is het kind even gauw voor den dag te doen komen als de gladde paling zich voortbeweegt.

Op Java draagt de diief een beentje van een kraai bij zich om even vlug en slim in het stelen te zijn als deze vogel.

Echter wordt niet alleen aan menschen maar ook wel aan beesten bestanddeelen van bepaalde dieren gegeven met het doel de eigenschappen van dit dier op den gebruiker te doen overgaan. Zoo worden op Java aan de paarden wel muizen te eten gegeven om ze vlug te doen zijn. ${ }^{6}$

De Galelareezen en Makassaren geven aan hanen duizend-

${ }^{1}$ N. Adriani en Albert C. Kruyt: De Bare'e-sprekende Toradja's van Midden-Celebes, deel III, 1914.

2 Van Ophnysen: Kijkjes in het huiselijk leven der Bataks. 1910.

3 J. Kreemer: De Javaan en zijn hoenders. Meded. vanwege het Nederl. Zendel. Gen., 36 $6^{\text {sto }}$ jaargang, 1893.

4 B. F. Matthes: Bijdragen tot de ethnologie van Zuid-Celebes, 1875.

s Batakspiegel. Uitgaven van het Bataksch Instituut, 1910.

${ }^{6}$ F. D. E. van Ossenbruggen: Het primitieve denken zooals dit zich uit in pokkengebruiken op Java en elders. Bijdr. T. L. en Vk. van Ned. Indiö deel $71,1915$. 
pooten te eten, om deze dieren dapper te maken $\mathrm{n}$ het hanengevecht. In de Soendalanden en bij de Toradja's legt men koppen van vergiftige slangen, duizendpooten en wespen onder een broedsel, opdat de hanen, welke uit dat broedsel voortkomen, dapper zullen zijn. ${ }^{1}$

Het gebruik der Javanen om aan zieke paarden en eveneens aan zulke dieren, die men dresseeren wil, gedroogde zeepaardjes toe te dienen, berust waarschijnlijk ook op de transmigratie theorie. ${ }^{2}$

Somtijds is het de naam van het dier, welke in bepaalde gevallen de aanwending van dat dier of de onthouding ervan motiveert.

Volgens Matthes behoort in Zuid-Celebes tot de huwelijksgeschenken een soort schelvisch, genaamd pånnno-pânno, mannetje en wijfje, vanwege de beteekenis van het woord pấnno, te weten die van $v o l$, hetwelk aan de jeugdige echtelingen veel voorspoed en rijkdom in het huwelijk voorspelt.

Als bij deze inlanders het huwelijk door de geboorte van een kind gezegend is en dit kind veertig dagen oud is geworden, geeft men een feest. Op dit feest wordt in een schotel met gewijd water een gedroogde staart van een onder den naam van mangâli bekende visch gelegd, die onwillekeurig aan het in het Boegineesch en Makassaarsch voor ons schromen gebezigde werkwoord mangâli doet denken. De naam van dien visch bevat eene vermaning voor het kind om later eene gepaste beschroomdheid bij het spreken in acht te nemen.

Boegineesche en Makassaarsche handelaars bevestigen aan hun winkel de kop van een jaarvogel, âlo geheeten, opdat de menschen niet (!?) verhinderd mogen worden om te komen koopen; dit âlo heeft namelijk de beteekenis van verhinderen. Evenzoo wordt wel opgehangen de kop van den tampalitto-vogel: volgens Matthes omdat die vogel steeds, met den snavel tegen den stam van de boomen kloppend, van beneden naar boven voortgaat en den winkelier alzoo gestadigen vooruitgang zijner zaken waarborgt.

Het geldt bij de Boegineezen voor pemali, dat kleine kinderen veel met kippen spelen, want daardoor loopen zij gevaar de

1 J. Habbema: Bijgeloof in de Preanger Regentschappen. Bijdr. T. L. en Vk. 6, VII, 1900 (geciteerd door Kruyt).

2 J. van Dongen: Beknopt overzicht der meest gebruikte geneesmiddelen in Nederlandsch Oost-Indië. 1913. 
vallende ziekte te krijgen. Dit ziet daarop, dat deze ziekte in het Boegineesch en Makassaarsch wordt aangeduid met eene uitdrukking, die letterlijk beteekent: spartelen als een kip, die ligt te sterven. (Boeg. mâte-mâte mâssóe; Mak. mâte-mâte djângang). ${ }^{1}$

Echter wordt van andere dieren of van bestanddeelen dezer dieren het gebruik aan zieken aanbevolen, omdat die dieren eenige eigenschappen gemeen hebben met de ziekte, waaraan de patienten lijdende zijn (signatuur). Zoo vernam ik van de Minangkabau-Maleiers in Sumatra, dat zij bij de barah kalalawar, de vleermuizenziekte, eene aandoening, waarbij zich een ettergezwel vormt in den oksel, ten einde dit absces te doen doorbreken, vleermuizenfaeces daarop smeeren en wel zoodanig, dat het centrale deel van het absces vrij blijft. Hier is het de overeenkomst in naam tusschen ziekte en medicament, welke de indicatie voor de aanwending geeft. ${ }^{2}$

Eene Toradja'sche hoofdendochter, die aan kleptomanie leed, werd genezen door eene der zake kundige vrouw, die een zak, waarin spinnen en krabben zich bevonden, welke door hunne kromme pooten als incarnaties der hebzucht worden beschouwd, op hare handen legde.

Merkwaardig is het gebruik der Toradja's in Koelawi om aan vruchtboomen een leguaan te hangen, ten einde ze tegen vruchtendieven te beschermen. De leguaan geldt n.l. als een dief bij uitnemendheid; men gelooft dat als een dief het mocht wagen vruchten te stelen van een boom, waaraan een leguaan is gehangen, hij zeker zal sterven. ${ }^{3}$

Ten slotte zij nog vermeld, dat onze inlanders sommige dieren juist zooveel mogelijk vermijden naar aanleiding van de bijzondere lichaamseigenschappen dezer dieren.

De Javanen b.v. zullen, om te voorkomen dat zij gaan lijden aan eene huidziekte, boelět genaamd, waarbij zich witte vlekken ontwikkelen op de handen en voeten, vermijden het vleesch te gebruiken van witte karbouwen, uit vrees dat de kracht, die zulke dieren eene lichte huid geeft, zal overgaan in het lichaam van den gebruiker, die daardoor boelet zou worden (Vorderman).

1 B. F. Matthes: Bijdragen tot de ethnologie van Zuid-Celebes, 1875.

2 J. P. Kleiweg de Zwaan: De Geneeskunde der Menangkabau-Maleiers, 1910.

3 N. Adriani en Albert C. Kruyt: De Bare'e-sprekende Toradja's van Midden-Celebes, deel I, 1912.

Dl. 71 . 
Aan. Toradja's, welke aan ichthyosis lijden, een ziekte waarbij zich schubben op de huid vormen, is het gebruik van kip en visch verboden. $\mathrm{Zij}$ mogen geen kip eten, omdat de pooten van dit dier geschubd zijn, en eveneens wordt hun het nuttigen van visschen ontzegd, omdat deze dieren schubben dragen. De Parigiërs en Saoesoeërs eten algemeen geen vleesch van witte buffels, omdat door het gebruik hiervan de witte vlekken op het lichaam zouden verschijnen, die bij lepra plegen voor te komen.

Eene Javaansche zwangere mag geen eieren, geen met stekels gewapende visschen en evenmin garnalen eten. Het gebruik van eieren zou veelvuldig terugkeerende valsche weeën veroorzaken en aan de zwangere onophoudelijk het gevoel geven, hetwelk een kip moet hebben, die haar ei niet kan kwijt raken. Door het gebruik van visschen met stekels riskeert de vrouw, dat hare bevalling moeilijk en langdurig zal zijn, terwijl het eten van garnalen eene pijnlijke verlossing teweegbrengt tengevolge van het onrustig heen en weer wentelen en draaien der vrucht. ${ }^{1}$

Ook in deze verbodsbepalingen herkent men het principe der transmigratie.

Een Niassch echtpaar zal tijdens de graviditeit der vrouw geen bujuwu (een vogel) eten, omdat men meent, dat het kind anders niet zou leeren spreken, maar zal schreeuwen gelijk deze vogel. Evenmin eet men in dien tijd uilenvleesch, ten einde te vermijden dat het kind het geroep van dit dier zou nabootsen. ${ }^{2}$

Een Javaan, die een doorn in zijn been krijgt, dient zich te onthouden van patil-visschen, daar deze harde en scherpe stekels bezitten. "

Volgens de inlanders van Zuid-Celebes mag op het feest aan het einde der zwangerschap eener vrouw geen enkel gerecht van beesten, die pooten bezitten, voorkomen, daar zulke beesten eenigermate op menschen gelijken. ${ }^{4}$

$\mathrm{Bij}$ verschillende Dajaksche stammen eten de mannen geen hertevleesch, omdat zij vreezen daardoor den schuwen aard van het hert te krijgen.

1 L. Th. Mayer, De Javaan als mensch en als lid van het Javannsehe huisgezin, 1894.

2 J. W. Thomas: Sitten und Aberglauben auf Nias. Globus 1881.

s Meded. vanwege het Nederl. Zendel. Gen., 34sto jaarg. 1890. Land-en Volkenk. ran Ned. Indië.

4 B. F. Matthes: Bijdragen tot de ethnologie van Zuid-Celebes. 1875. 
Ook vermijdt een Niassch echtpaar tijdens de graviditeit der vrouw naar een doode slang te zien, want het kijken naar een doode slang zou tengevolge hebben, dat het kind niet leert loopen, maar op den grond kruipt als een slang. ${ }^{1}$ Mocht de zwangere of haar echtgenoot bij ongeluk toch ergens een doode slang zien liggen, dan moet men om het onheil van het kind af te wenden, een slang dooden en verbranden.

In dat gebruik ligt waarschijnlijk opgesloten het veelvuldig bij onze inlanders voorkomend denkbeeld, dat men den schadelijken invloed van een of ander dier slechts ongedaan kan maken door aanwending van bestanddeelen, van zoo'n zelfde dier af komstig.

Uit hetgeen werd medegedeeld kunnen wij afleiden en besluiten :

$1^{\mathrm{e}}$. Dat bij onze inlanders de neiging bestaat eene verklaring te geven, zij het dan ook vaak op fantastische en speculatieve wijze, van de bijzondere somatische eigenschappen der dieren.

$2^{\text {e }}$. Dat bij hen evenzeer verhalen in omloop zijn, die bedoelen eene verklaring der opvallende gewoonten van bepaalde dieren.

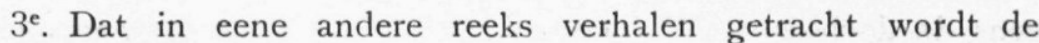
namen der dieren te verklaren.

4 e. Dat de karakteristieke somatische of functioneele eigenschappen van sommige dieren onzen inlanders aanleiding hebben gegeven die dieren voor bepaalde doeleinden te gebruiken of juist het gebruik daarvan te vermijden.

$5^{\text {e }}$. In sommige gevallen is het de naam van het dier, door welken de aanwending van dat dier of de onthouding ervan wordt bepaald.

Zulke gebruiken of verbodsbepalingen berusten ten deele op den leer der transmigratie of op dien der signatuur.

Ik acht mij niet bevoegd te beoordeelen, in hoeverre de medegedeelde verhalen in onzen Oost oorspronkelijk zijn en in hoeverre ontleend, casu quo aan welke volken. Om dat uit te maken zou ik de hulp en voorlichting willen inroepen van diegenen, welke soortgelijke verhalen bij andere volken hebben bestudeerd.

Gebleken is het, dat de verhalen, verklarende den naam en

1 Elio Modigliani: Un Viaggio a Nias, Milano 1890. 
de eigenaardige somatische eigenschappen der dieren en hunne bijzondere gewoonten, over den geheelen Indischen Archipel verspreid voorkomen. Immers wij leerden ze kennen o. a. bij de Maleiers van Malakka, Atjehers, Bataks, Javanen en Soendaneezen, verschillende Dajaksche stammen, bij de Boegineezen en Makassaren, de Galelareezen, Toradja's, Rottineezen en Alfoeren.

Diezelfde poging tot verklaring komt tot uiting in de legenden en verhalen van tal van andere volken. Een paar voorbeelden mogen hier volstaan, ten bewijze tevens van het gelijkwaardig en gelijksoortig denken in menig opzicht over de geheele wereld!

Volgens de Grieksche mythe was eertijds de raaf, Apollo's bode, wit van kleur. Toen het dier echter op zekeren dag zijn meester kwam vertellen, dat diens geliefde, Coronis, de dochter van Phlegyas, heimelijk omgang had met Ischys, maakte Apollo in zijn toorn de raaf zwart en doodde Coronis met haar minnaar. Sinds dien is de raaf steeds zwart van kleur gebleven. (Pindarus).

De Fellach, ten zuiden van Bethlehem wonend, vertelt, dat eens de dochter van Mohammed Fâtine haar buurvrouw verzocht had in haar bakoven brood te mogen bakken. De vrouw antwoordde echter, dat het vuur in de oven niet brandde. In werkelijkheid echter had zij zelf den oven in gebruik. Tot haar straf werd zij door God in een schildpad veranderd. Als herinnering aan haar misdaad draagt zij op haar rug den oven als hare woning; de vlekken op het schild stellen de steenen voor, die in den oven gebruikt worden. $\mathrm{Zij}$ had zich niet gehouden aan het 'gebod nooit aan den naaste iets te weigeren, wat voor de bereiding van het brood noodig is.

Volgens een ander verhaal dezer Fellachs zou het stekelzwijn in vroeger tijd een mensch zijn geweest, die in een klein dorpje leefde. Hij was listig en gierig. Op zekeren dag bezocht hij den schoenmaker van het dorp, een armen maar vlijtigen handwerker. Bij het vertrek nam hij heimelijk den priem van den schoenmaker weg. Overal zocht deze naar zijn priem en daar hij door het verlies van zijn instrument zijn handwerk niet kon uitoefenen, smeekte hij, dat den dief het werktuig tot een eeuwige plaag zou worden. Wegens zijn misdrijf werd de dief in een stekelvarken veranderd, wiens stekeldracht eene blijvende herinnering 
is aan het gepleegde onrecht, het stelen van de priem van den schoenmaker. ${ }^{1}$

In deze legenden is dus evenals in verschillende der medegedeelde Indische verhalen sprake van de verandering van den mensch in een dier, welke verandering als een straf is bedoeld.

Waarom de shiwan, een klein geel insect, op de komkommers leeft, verklaart ons eene Japansche legende. Eertijds is de shiwan een geneesheer geweest. Deze had zich echter aan een misdrijf schuldig gemaakt en toen hij zijn woonplaats trachtte te ontvluchten, geraakte hij met de voeten in komkommerstengels verward. Hij werd door zijn vervolgers gedood, zijn geest werd een shiwan, welke van dien tijd af op de komkommers pleegt te leven. ${ }^{2}$

Het vermijden van bepaalde dieren, ten einde te voorkomen, dat de bijzondere somatische kenteekenen zich bij den gebruiker zullen openbaren, komt eveneens bij tal van andere volken voor. Zoo is het b.v. in den Kongo taboe het vleesch te eten van vogels en visschen, die vlekken op het lichaam hebben; degeen die zich aan deze verbodsbepaling niet houdt, zal eene huidziekte krijgen, waarbij vlekken op de huid ontstaan. De Indianen van Britsch-Guiana verbieden den echtgenoot eener zwangere vrouw dieren met vooruitstaande tanden te eten, want daardoor zal het kind later ook zulke tanden krijgen. Evenmin mag hij het vleesch van een gevlekt dier gebruiken, want dat bezorgt het kind eene vlekkige huid. In dit geval is het dus niet de gebruiker zelf, die door zijn verkeerde daad lijdt, maar het kind, waarvan de vrouw tijdens het plegen van die daad zwanger was.

1 T. Canaan: Aberglaube und Volksmedizin im Lande der Bibel. Abhandl. des Hamburgischen Kolonialinstituts, Band XX, 1914.

2 F. Hadland Davis: Myths and Legends of Japan. 1912. 